\title{
PENGARUH KADAR BENZENE DALAM DARAH DAN KARAKTERISTIK PEKERJA TERHADAP PROFIL DARAH PEKERJA \\ (Di PT. Laju Luas Indonesia)
}

Rachma Azzavira*, Demes Nurmayanti, Rachmaniyah

Jurusan Kesehatan Lingkungan Poltekkes Kemenkes Surabaya

*Email korespondensi: rachmazavira@gmail.com

\begin{abstract}
ABSTRAK
Paparan bau yang diakibatkan oleh benzene dapat menyebabkan perubahan kadar profil darah pada tenaga kerja di PT.X. Perubahan kadar profil darah yang diakibatkan oleh kadar benzene di tempat kerja ini dapat mengakibatkan penyakit seperti leukemia. Tujuan utama dari penelitian ini adalah mengetahui pengaruh kadar benzene dalam darah dan karakteristik pekerja dengan profil darah pekerja.

Penelitian ini merupakan penelitian observasional dengan metode cross sectional. Teknik pengambilan sampel menggunakan Random Sampling sebanyak 14 pekerja di bagian produksi. Pengumpulan data menggunakan hasil laboratorium, observasi, dan wawancara. Analisis data dilakukan menggunakan uji Korelasi Produk Moment dan uji alternatifnya Rank Spearman.

Hasil penelitian menunjukkan tidak adanya pengaruh signifikan karakteristik IMT, masa kerja, dan riwayat lama merokok dengan hemoglobin, sel darah merah dan MCV, sedangkan untuk karakteristik usia dan kebiasaan merokok serta kadar benzene dalam darah ada pengaruh signifikan dengan MCV, namun tidak ada pengaruh signifikan dengan hemoglobin dan sel darah merah.

Kadar benzene yang tinggi dibagian produksi dapat beresiko terhadap penyakit akibat kerja. Saran untuk perkeja untuk tetap menjaga jam istirahat serta mengurangi kebiasaan merokok pada saat bekerja. Bagi industri hendaknya melakukan controlling pada kebijakan terumata untuk K3 di bagian produksi.
\end{abstract}

Kata kunci: Benzene, profil darah, karakteristik pekerja.

\section{PENDAHULUAN}

Kesehatan dan keselamatan kerja atau yang sering disebut dengan K3 merupakan upaya untuk menjamin keutuhan dan kesempurnaan baik jasmani maupun rohani. Kecelakaan dan penyakit akibat kerja sangat erat kaitannya dengan pelaksanaan $\mathrm{K} 3$. Hal ini telah diatur pada Permenaker no. 5 tahun 2018 menyatakan tiap tenaga kerja berhak mendapatkan perlidungan atas keselamatan, kesusilaan, pemeliharaan moril kerja serta perlakuan yang sesuai dengan martabat manusia dan moral agama. Selain itu penerapan K3 juga tertuang dalam UU No. 36 Tahun 2009 tentang kesehatan dalam bab xii yang terdiri dari pasal 164 hingga 166. Kesehatan kerja adalah spesialisasi dalam ilmu kesehatan/kedokteran dengan praktiknya bertujuan agar pekerja memperoleh derajat kesehatan yang setinggi-tingginya, baik fisik maupun mental dan social dengan usaha promotif dan kuratif, terhadap penyakit/gangguan kesehatan yang diakibatkan faktor-faktor pekerjaan dan lingkungan kerja.

Menurut perkiraan data oleh Organisasi Perburuhan Internasional (ILO) pada tahun 2017, sekitar 2,78 juta pekerja meninggal setiap tahun karena kecelakaan kerja dan penyakit akibat kerja. Kecelakaan kerja dapat menyebabkan penderitaan manusia yang tak terhitung, selain itu juga dapat menyebabkan kenaikan biaya ekonomi yang signifikian, dengan perkiraan kerugian tahunan sebesar 3,94 persen dari PDB global (ILO, 2017).

Ada beberapa faktor penyebab dari penyakit akibat kerja salah satunya adalah bahan kimia. Bahan kimia dapat digunakan sebagai bahan tambahan untuk produksi maupun bahan utama dari industry. Beberapa industry yang menggunakan bahan kimia untuk bahan tambahan yaitu industry tekstil, fiber, kulit, kertas, pelapis listrik, pengolahan logam dan obat-obatan (CDC, 2005). 
Benzene merupakan salah satu bahan kimia yang terdapat pada bahan perekat atau lem di industri sepatu, fiber dan kulit. Pada industry fiber bahan perekat digunakan di bagian perakitan untuk merakit menjadi suatu product. Bahan kimia ini memiliki sifat toxic, notasi bahaya "toxic" dapat menyebabkan kerusakan kesehatan akut atau kronis dan bahkan kematian pada konsentrasi sangat rendah jika masuk ke tubuh melalui inhalasi, mulut atau kontak dengan kulit (ILO, 2017).

Benzena dalam bentuk gas yang terhirup oleh manusia dengan kadar yang tinggi dalam waktu singkat akan memberikan efek pada sel darah dan sumsum tulang belakang yang merupakan tempat pembentukan sel darah. Pada percobaan yang dilakukan melalui hewan ujicoba, didapatkan hasil paparan benzene akan menyebabkan penurunan semua tipe sel darah yang menyebabkan anemia, kekebalan tubuh berkurang terhadap penyakit, serta gangguan kemampuan pembekuan darah. U.S. Environmental Protection Agency (EPA) mengklasifikasikan benzene sebagai zat kimia yang tergolong karsinogenik. Paparan benzene melalui inhalasi akan menyebabkan penyakit leukemia dan anemia. (Sheet, 2013)

Hasil survey pendahuluan yang dilakukan di industri fiber beralamat di Taman Pondok Jati AK-16 melalui wawancara dan pengukuran kadar benzene di lingkungan kerja yang telah dilakukan pada 27 September 2019 - 12 November 2019 didapatkan bahwa kadar benzene di lingkungan kerja berada dalam kisaran 2,76-16,68, dengan rincian Area perakitan bioseptik $=16,68 \mathrm{ppm}$ dan area produksi atap $=2,76$. Kisaran ini berada di atas batas paparan yang direkomendasikan oleh Permenaker No. 05 Tahun 2018 tentang keselamatan

lingkungan kerja, yaitu sebesar 0,5 ppm. Pada survey pendahuluan juga didapatkan bahwa industri ini telah menerapkan $\mathrm{K} 3$ dasar seperti penggunaan APD, adanya rambu-rambu K3 di bagian produksi, terdapat apar di sebagian titik produksi. Namun, pada pelaksanaannya tenaga kerja tidak menggunakan APD saat produksi. Hal ini dapat menyebabkan timbulnya penyakit akibat kerja terhadap pekerja, dimana pada beberapa proses produksi yang dilakukan pekerja mengalami kontak langsung dengan bau menyengat dari bahan perekat dari resin. Seperti yang kita ketahui dalam resin terdapat bahan kimia benzene dalam proses pembuatannya (Yuniati, 2016).

Berdasarkan studi yang telah dilakukan, peneliti akan meneliti tentang penyakit akibat kerja yang dihasilkan oleh paparan benzene di lingkungan kerja yang melebihi baku mutu. Mengingat benzene merupakan salah satu bahan kimia yang mudah terakumulasi dalam darah. Oleh karena itu peneliti tertarik untuk meneliti hubungan kadar benzene dalam darah terhadap profil darah pekerja di PT. X.

\section{METODE PENELITIAN}

Jenis penelitian yang dilakukan dengan menggunakan pendekatan cross sectional. Teknik pengumpulan data dengan melakukan observasi, wawamcara, dan pengukuran. Penelitian dilakukan di ruang workshop industri fiber dengan jumlah sampel 14 pekerja.

Variable terikat dari penelitian ini adalah profil darah pekerja di PT.X. Variable bebas pada penelitian ini adalah kadar benzene dalam darah dan karakteristik pekerja yang meliputi usia, IMT, kebiasaan merokok, dan riwayat lama merokok.

Analisi yang digunakan dalam penelitian ini menggunakan analisis univariat dan analisis bivariate. Analisis univariat bertujuan untuk melihat gambaran distribusi frekuensi dan presentase masing-masing variable. Analisis bivariate bertujuan untuk melihat korelasi variable dependen dan independen menggunakan uji Shapirowilk, yang selanjutnya diuji dengan uji korelasi product moment atau rank spearman. 
HASIL DAN PEMBAHASAN

Tabel 1

HASIL NILAI MIN-MAX, RATA-RATA DAN STD DEVIASI KARAKTERISTIK RESPONDEN, KADAR BENZENE DI LINGKUNGAN KERJA, KADAR BENZENE DALAM DARAH DAN PROFIL DARAH RESPONDEN

\begin{tabular}{lllll}
\hline No. & \multicolumn{1}{c}{ Variable } & \multicolumn{1}{c}{ Nilai Min-Max } & Rata-Rata & Std. Deviasi \\
\hline 1. & Kadar benzene tempat kerja & $2,76-16,68$ & $9,72 \mathrm{ppm}$ & 9,84 \\
\hline 2. & $\begin{array}{l}\text { Kadar benzene dalam darah } \\
\text { pekerja }\end{array}$ & $13,2-32,6 \mu \mathrm{g} / \mathrm{l}$ & $21,77 \mu \mathrm{g} / \mathrm{l}$ & 6,39 \\
\hline 3. & $\begin{array}{l}\text { Profil darah pekerja } \\
\text { a. Hemoglobin }\end{array}$ & $13,8-17,7 \mathrm{~g} / \mathrm{dL}$ & $15,18 \mathrm{~g} / \mathrm{dL}$ & $1,03 \mathrm{~g} / \mathrm{dL}$ \\
& $\begin{array}{l}\text { b. Sel Darah Merah } \\
\text { c. MCV }\end{array}$ & $4,4910^{6}-6,0410^{6} / \mu \mathrm{L}$ & $5,0510^{6} / \mu \mathrm{L}$ & $0,4510^{6} / \mu \mathrm{L}$ \\
& & $80,3 \mathrm{fl}-106,8 \mathrm{fl}$ & $92,73 \mathrm{fl}$ & $0,705 \mathrm{fl}$
\end{tabular}

\begin{tabular}{lllll}
\hline 4. & Masa kerja & $8-120$ bulan & 39,2 bulan & 37,19 bulan \\
\hline 5. & Kebiasaan Merokok & $8-20$ batang/hari & $\begin{array}{l}12,20 \\
\text { batang/hari }\end{array}$ & $\begin{array}{l}3,55 \\
\text { batang/hari }\end{array}$ \\
\hline 6. & Riwayat Lama Merokok & $3-50$ tahun & 24,6 tahun & 13,04 tahun \\
\hline 7. & Usia & $21-68$ tahun & 42,67 tahun & 12,99 tahun \\
\hline 8. & IMT & $18,86-27,71$ & 23,19 & 2,88 \\
\hline
\end{tabular}

Faktor-faktor yang mempengaruhi perubahan profil darah yang diakibatkan dari paparan benzene dari proses produksi yang dilakukan oleh responden. Faktor utama dari perubahan profil darah pekerja adalah kadar benzene dalam darah. Faktor lain yang mempengaruhi perubahan profil darah adalah karakteristik responden meliputi usia, masa kerja, IMT, konsumsi rokok tiap harinya, dan riwayat lama merokok. (Yunita, 2016)

\section{Pengaruh Usia terhadap Profil Darah Pekerja}

Usia memiliki faktor penting dalam pembentukan darah pada manusia. Seseorang dengan usia $\geq 40$ tahun dapat mengalami penurunan faal organ tubuh yang menyebabkan metabolisme menjadi terganggu. Usia sesroang mempengaruhi daya tahan tubuh seseorang dari zat kimia berbahaya (Erini Meilana Bestari, 2019). Daya tahan tubuh yang rentan dapat menyebabkan zat kimia seperti benzene dapat masuk dalam tubuh dan mengganggu kerja sumsum tulang belakang. Pekerja yang berusia kurang dari 18 tahun dianjurkan untuk tidak bekerja di lingkungan yang terpajan benzene karena pada usia tersebut ketahanan sumsum tulang belakang efek toksik benzene masih rendah (Parinduri, 2018).

Sumsum tulang belakang merupakan target utama pajanan benzene yang berfungsi sebagai pembentukan darah. Tergangggunya sumsum tulang belakang akan menyebabkan penurunan produksi sel darah merah yang mengakibatkan anemia. Pada hasil pemeriksaan sel darah merahdidapatkan 1 dari 15 pekerja diatas nilai rujukan $6,0410^{6} / \mu \mathrm{L}$ dan berusia 39 tahun dan hasil pemeriksaan hemoglobin didapatkan $7,14 \%$ dari seluruh pekerja diatas nilai rujukan $17,7 \mathrm{~g} / \mathrm{dL}$ dan berusia 46 tahun, sehingga usia tidak mempengaruhi jumlah sel darah merah dan hemoglobin.

Hasil analisa yang dilakukan tentang pengaruh usia terhadap mean cospuslar volume memiliki nilai korelasi yang tinggi $p$ 0,009. Sebesar 28,57\% dari total responden memiliki nilai mean cospuslar volume tinggi dengan usia $>55$ tahun. Nilai mcv yang besar tinggi ini menunjukkan ukuran eritrosit yang besar, yang menjadi salah satu faktor terjadinya anemia megaloblastik. Anemia ini terjadi akibat terganggunya sintesis DNA pada 
proses pematangan sel darah merah yang terjadi di sumsum tulang (Pesatori AC G. S., 2009). Hal ini sejalan dengan penelitian yang dilakukan Wahida (2016) terjadi penurunan rata-rata hematologi pada usia rentan $>40$ tahun dengan pengecualian bahwa nilai Mean Corpuscular volume (MCV) justru meningkat.

Pekerja dengan usia $>40$ tahun sangat rentan untuk terpapar zat kimia berbahaya lainnya. Karbon monoksida merupakan zat kimia yang berbahaya, mengingat pekerja juga terpapar $\mathrm{CO}$ dari perjalanan ke tempat kerja dan kebiasaan merokok yang dilakukan (Pratiwi, 2018). Karbon monoksida mampu mengikat $\mathrm{Hb}$ dalam darah sehingga menyebabkan sesak nafas. Penanggulangan untuk mengurangi dan mencegah terjadinya penyakit akibat kerja, sebaiknya perusahaan melakukan rolling pekerja dalam proses produksi khususnya yang berusia > 40 tahun serta pendisiplinan pemakaian alat pelindung diri (APD) agar mengurangi risiko kontak langsung dengan bau benzene (Majid, 2011).

\section{Pengaruh IMT terhadap Profil Darah Pekerja}

Hasil analisis yang dilakukan untuk mengetahui pengaruh Indeks Masa Tubuh terhadap profil darah yang meliputi hemoglobin, sel darah merah, dan mean corpuscular volume menggunakan Korelasi Product Moment mendapatkan nilai $p$ berturut-turut $0,577,0,614$, dan 0,209 . Nilai $p$ yang dihasilkan $(p>0,05)$ menunjukkan tidak ada korelasi yang kuat antara indeks masa tubuh dengan profil darah.

Proses pembentukan darah (Hematopoeisis) akan berjalan dengan baik apabila asupan gizi yang dikonsumsi cukup untuk pembentukan sel-sel darah sehingga pembentukan sel darah berjalan dengan normal (Ramon, 2007). Asupan gizi yang dianjurkan dalam proses pembentukan darah diantaranya $\mathrm{Fe}$, vitamin $B_{12}$, dan protein. Keterkaitan zat besi dengan pembentukan darah sangat kuat hal ini disebabkan karena zat besi memiliki peranan penting sebagai komponen utama dalam pembentukan darah (hemopoiesis) atau proses mensintesis hemoglobin. Jumlah zat besi yang berlebih akan disimpan sebagai protein ferritin, sumsum tulang belakang, dan selebihnya di dalam limpa dan otot. Simpanan zat besi yang cukup ini juga untuk pembentukan sel darah merahdalam sumsum tulang. Apabila jumlah simpanan zat besi ini kurang dan jumlah zat besi yang diperoleh dari makanan juga rendah, maka akan terjadi ketidakseimbangan zat besi dalam tubuh dan berakibat kadar hemoglobin menurun di bawah batas normal atau yang disebut sebagai anemia gizi besi (Indriasari, 2013).

Implikasinya, tidak ada pengaruh indeks masa tubuh dengan perubahan profil darah pekerja PT. Laju Luas Indonesia, namun $42,86 \%$ dari total responden masih ditemukan memiliki indeks masa tubuh yang melebihi standar. Hal ini sejalan dengan penelian yang dilakukan Abdul Rohim, 2019 yang meneliti hubungan Excess Cancer Risk (ECR) dengan menghitung berat badan dan profil darah pekerja di industri sepatu yang terpapar benzene, didapatkan hasil tidak adanya hubungan ECR dengan blood profile, namun terdapat beberapa pekerja yang memiliki berat badan tidak normal. Hasil wawancara yang telah dilakukan pada pekerja yang memiliki IMT diatas standar ini memiliki kebiasaan mengkonsumsi kopi pada malam hari yang menyebabkan waktu tidur yang kurang. Kurangnya waktu tidur juga berdampak pada perubahan hormonal dan metabolisme yang berkontribusi terhadap kenaikan berat badan dan obesitas. Pekerja perlu memperhatikan waktu istirahat pada malam hari dan mengurangi kebiasaan mengkonsumsi kopi pada malam hari. Sedangkan perusahaan perlu memperhatikan asupan gizi yang diberikan kepada tenaga kerja.

\section{Pengaruh Masa Kerja terhadap Profil Darah Pekerja}

Hasil olah data yang dilakukan menggunakan Rank Spearmanmasa kerja terhadap profil darah meliputi hemoglobin, sel darah merah dan mean corpuscular volume berturut-turut menunjukkan hasil nilai $p=0,380,0,816$, dan 0,254 atau nilai $p>0,05$ yang 
memiliki arti tidak ada pengaruh signifikan masa kerja terhadap profil darah pekerja PT. Laju Luas Indonesia. Hal ini terjadi karena banyaknya variasi masa kerja pekerja di PT. Laju Luas Indonesia. Hasil wawancara diketahui bahwa pekerja memiliki masa kerja 8 bulan hingga 120 bulan dengan rata-rata 39,2 bulan atau 3 tahun.

Keracunan benzene akan terjadi jika masa kerja tenaga kerja $\geq 3$ tahun. Selain itu, sebagaian besar $(66,67 \%)$ pekerja di PT. Laju Luas Indonesia tidak menerima paparan benzene di tempat kerja sebelumnya. Riwayat pekerjaan sebelumnya yaitu berdagang, supir, jual beli alat elektronik, dan bekerja di kontruksi bangunan. Masa kerja merupakan lamanya seseorang terpajan benzene pada saat bekerja dalam hitungan tahun. Pada teorinya masa kerja mempengaruhi besarnya pengaruh seseorang terpanjan benzene (Yuniati, 2016), pajanan benzene ini dapat menyebabkan gangguan pada sumsum tulang sehingga pembentukan darah yang tidak berjalan normal. Pembentukan darah yang terganggu ini akan menyebabkan perubahan profil darah pada pekerja yang terpajan benzene.

Implikasinya tidak ada pengaruh signifikan masa kerja terhadap profil darah hal ini sejalan dengan penelitian Huda Mohammed, 2018 dimana masa kerja yang diduga berpengaruh terhadap perubahan profil darah pekerja yang terpajan benzene ternyata memiliki korelasi negatif. Hal ini disebabkan karena masa kerja tidak secara langsung berperan dalam proses pembentukan selsel darah. Penelitian lain yang dilakukan oleh Wahida, 2016 tentang hubungan paparan benzene dengan profil darah pada pekerja juga tidak menunjukkan hubungan signifikan antara masa kerja dengan perubahan profil darah pekerja

\section{Pengaruh Kebiasaan Merokok dan Riwayat Lama Merokok terhadap Profil Darah Pekerja}

Hasil olah data menggunakan Korelasi Product Moment kebiasaan merokok terhadap profil darah meliputi hemoglobin, sel darah merah, dan mean corpuscular volume didapatkan hasil nilai $p$ berturut-turut $0,424,0,946$, dan 0,004 yang berarti tidak ada pengaruh signifikan antara kebiasaan merokok terhadap hemoglobin dan sel darah merah, namun ada pengaruh signifikan kebiasaan merokok dengan mean corpuscular volume. Sedangkan hasil olah data menggunakan Korelasi Product Moment riwayat merokok terhadap profil darah meliputi hemoglobin, sel darah merah, dan mean corpuscular volume didapatkan hasil nilai $p$ berturut-turut $0,401,0,991$, 0,544 atau $p>0,05$ yang dapat diartikan tidak ada pengaruh signifikan antara riwayat merokok terhadap profil darah.

Merokok merupakan salah satu sumber dari pajanan benzene yang berupa asap rokok (ASTDR, Toxicological Profile for Benzene, 2007). Di udara asap rokok menjadi sumber benzene terutapa di lingkungan atau ruangan yang memiliki kadar benzene lebih tinggi jika seseorang merokok (WHO, 2010)yang berarti semakin banyak seseorang mengkonsumsi rokok semakin banyak pula pajanan benzene dalam tubuh seseorang tersebut. Penelitian sama yang dilakukan oleh Andrian, 2020 tentang pengaruh karakteristik terhadap kadar benzene dalam darah pekerja di PT. Laju Luas Indonesia menunjukkan korelasi positif pengaruh kebiasaan merokok dan riwayat lama merokok dengan kadar benzene dalam darah. Kadar benzene dalam darah yang melebihi baku mutu dapat menyebabkan terganggunya sumsum tulang belakang dalam pembentukan darah mengingat target utama toksik benzene adalah sumsum tulang belakang.

Studi yang dilakukan oleh Hanum, 2002 menyimpulkan bahwa gas CO dari asap rokok tidak mempengaruhi jumlah hemoglobin, namun $\mathrm{CO}$ yang berada pada asap rokok berefek pada kemampuan $\mathrm{Hb}$ dalam mengikat atau mendistribusikan $\mathrm{O}_{2}$ melalui sel darah merah. Hal ini sejalan dengan hasil studi yang dilakukan oleh Inal, 2014 tentang efek merokok terhadap kesehatan hematologi lelaki bahwa tidak ditemukan pengaruh yang signifikan antara kebiasaan merokok dengan hematologi (hemoglobin dan sel darah merah) kecuali kadar mean corpuscular volume yang meningkat. Meningkatnya 
mean corpuscular volume dalam darah menunjukkan nilai sel darah merah yang besar (Makrositik) hal ini merupakan kondisi klinis anemia megaloblastik. Anemia ini terjadi karena terganggunya sintetis DNA yang pada proses pembentukan sel darah merah di sumsum tulang belakang. Hal ini menyebabkan pembelahan sel berlangsung lambat.

Maka diharapkan untuk tenaga kerja untuk menaati peraturan perusahaan untuk tidak merokok pada saat bekerja dan mengurangi kebiasaan merokok diluar pekerjaan agar kandungan benzene dalam darah tidak melebihi baku mutu dan dapat menyebabkan penyakit akibat kerja.

\section{Pengaruh Kadar Benzene dalam Darah terhadap Profil Darah Pekerja}

Hasil olah data yang dilakukan menggunakan Korelasi Product Moment pengaruh kadar benzene dalam darah terhadap profil darah meliputi hemoglobin, sel darah merah, dan mean corpuscular volume didapatkan hasil nilai $p$ berturut turut $0,401,0,991$, dan 0,000 yang berarti tidak ada pengaruh signifikan kadar benzene dalam darah terhadap hemoglobin dan sel darah merah, namun terdapat hubungan signifikan kadar benzene dalam darah dengan mean corpuscular volume. Hal ini dapat dilihat dari nilai $p<0,05$.

Kadar benzene dalam darah merupakan kandungan benzene yang terlarut dalam darah pada satuan $\mu \mathrm{g} / \mathrm{L}$. Nilai mcv yang meningkat ini dapat menyebabkan anemia megaloblastik, anemia ini terjadi akibat terganggunya sintesis DNA di sumsum tulang. Kandungan benzene dalam darah mempengaruhi sintetis DNA dari reaksi metabolit benzene oksida yang berikatan dengan asam nukleat. Reaksi ini menyebabkan prekusor sel darah hanya memiliki kemampuan untuk memproduksi senyawa untuk duplikasi gen, sedangnya senyawa yang digunakan untuk menonaktifkan mutasi tersebut tidak dihasilkan sumsum tulang (Pesatori AC G. S., 2009). Hal ini menyebabkan gen yang terduplikasi semakin meningkat hingga menimbulkan kerusakan genetic DNA precursor sel darah. Kerusakan DNA ini menyebabkan ketidakseimbangan proses pematangan nucleus dan sitoplasma sel darah merah yang diproduksi memiliki ukuran lebih besar dari normal (ASTDR, Toxicological Profile for Benzene, 2007).

Tingginya nilai MCV pada darah dan rendahnya sel darah merah juga dipengaruhi oleh vitamin B12 atau asam folat yang dapat menyebabkan anemia megaloblastik. Pada umumnya anemia ini ditandai dengan sel darah merah makrositik. Kurangnya konsumsi vitamin B12 atau asam folat ini dapat mempengaruhi sintesis DNA pada tunastunas sel darah merah. Namun, pada penelitian ini tidak dilakukan pengukuran kadar B12 dan asam folat pada pekerja. sehingga tidak dapat dipastikan pengaruhnya terhadap anemia megaloblastik (Schick P, 2014).

Hasil analisa yang dilakukan terdapat $28,57 \%$ responden memiliki nilai mcv yang cenderung melebihi nilai rujukan juga memiliki kadar benzene dalam darah yang melebihi baku mutu. Hal ini sejalan dengan penelitian Kamal dan Malik 2012 tentang gambaran hematologi pada pekerja yang terpapar benzene, menyimpulkan bahwa rata-rata nilai $\mathrm{mcv}$ pada pekerja penyemprotan cat mobil lebih tinggi jika dibandingkan dengan kelompok control, sedangkan parameter hematologi lain mengalami penurunan dari kelompok control. Penelitian lain yang dilakukan oleh Wahida 2016 juga menyebutkan bahwa tidak ada hubungan signifikan antara paparan benzene dengan jumlah hemoglobin, sel darah merah, sel darah putirh, trombosit, pada pekerja. Namun, terdapat hubungan signifikan kadar benzene dengan jumlah mcv pekerja. sehingga dapat disimpulkan kerusakan sumsum tulang belakang dalam proses pembentukan darah masih relative ringan. Penelitian ini sejalan dengan teori penurunan jumlah elemen darah secara keseluruhan akan tampat jelas pada paparan benzene yang lama dan kadar benzene diatas 100 ppm.

Responden yang bekerja dan mengalami kontak langsung dengan pajanan benzene diharap mentaati peraturan perusahaan untuk memakai APD sebagai salah satu upaya pencegahan agar penyakit akibat kerja 
yang diterima tidak lebih parah. Bagi perusahaan diharapkan mampu melakukancontrollingdan monitoring terhadap system K3 khususnya bagi tenaga kerja yang berada di workshop.

\section{KESIMPULAN}

Kadar benzene pada udara workshop kerja PT. Laju Luas Indonesia adalah pada area perakitan bioseptik $16,68 \mathrm{ppm}$ dan area produksi atap 2,76 ppm.

Hasil analisis didapatkan tidak ada pengaruh signifikan perubahan profil darah terhadap indeks masa tubuh, masa kerja dan riwayat lama merokok. Tidak ada pengaruh signifikan usia, kebiasaan merokok, kadar benzene dalam darah terhadap jumlah hemoglobin dan sel darah merah responden. Ada pengaruh signifikan usia dan kebiasaan merokok dengan jumlah mean corpuscular responden.

\section{SARAN}

Bagi perusahaan disarankan untuk melakukan review tentang kebijakan $\mathrm{K} 3$, memperhatikan asupan gizi pekerja, melakukan briefing dan safety induction setiap pergantian shift. Bagi tenaga kerja disarankan untuk memperhatikan jam tidur, mengurangi kebiasaan merokok, dan menggunakan ADP saat bekerja.

\section{DAFTAR PUSTAKA}

Erini Meilana Bestari, S. L. (2019). SUMBER BENZENA, KARAKTERISTIK DAN KADAR HEMOGLOBIN MEKANIK BENGKEL MOTOR AHASS KOTA KEDIRI . Jurnal Kesehatan Lingkungan .

Inal, B. (2014). Effects of smoking on healthy young men's hematologic parameters. Northem Clinics of Istanbul.

Indriasari, R. (2013). Hubungan Asupan Zat Gizi Pembentuk Sel Darah Merah dengan Kadar Hemoglobin Pada Ibu Hamil di Kabupaten Gowa.

Kamal A, M. R. (2012). Hematological Evidence of Occupational Exposure to Chemicals and Other Factors among Auto-Repair Workers in Rawalpindi Pakistan. Osong Public Health Res Perspect.
Majid. 2011. Racun Gas Karbon Monoksida. http://Racun Gas Karbon Monoksida.pdf-Adobe Reader

Mohammed, H. (2018). hematological Assessment of Benzene Exposure Among Employess in Ras-Elmengar Depository of El-Brega Company, Beghanzi. Enviromental \& Analytical Toxicology.

Parinduri. (2018). Hubungan Paparan Benzena dengan Anemia pada Pekerja Industri Percetakan di Kota Medan Tahun 2018. Repositori Institusi USU.

Pesatori AC, G. S. (2009). Early Effects of Low Benzene Exposure on Blood Cell Counts in Bulgarian Petrochemical Workers. Med Lav.

Pratiwi, D. R. (2018). Gambaran Kadar $\mathrm{HbCO}$ dalam Darah Pada Masyarakat Dusun Demeling, Gedangan, Sidoarjo. GEMA KESEHATAN LINGKUNGAN.

Ramon, A. (2007). Analisis Paparan Benzena Terhadap Profil Darah Pada Pekerja Industri Pengolahan Minyak BUmi.

Safithri, R. (2017). Profil Darah Pekerja SPBU yang Terpapar Benzena.

Schick P, T. F. (2014). Megaloblastic Anemia. Retrieved from http://emedicine.medscape.com/a rticle/204066-overview\#showall.

WHO. (2010). Exposure to benzene : A Major Public Health Concern. Retrieved from WHO Document Production Services. Retrieved from https://www.who.int/ipcs/features/b enzene.pdf

Yuniati, I. (2016). Hubungan Praktik Kerja, Pajanan Benzena dan Kebiasaan Merokok dengan Konsentrasi Benzene dalam Urin. 